\title{
RHETORICAL STRATEGY AND LINGUISTICS FEATURES IN E-PETITION THROUGH CHANGE.ORG
}

\author{
Nurrahma Restia Fatkhiyati \\ Department of Linguistics, Faculty of Humanities, Diponegoro University \\ Jl. Prof. Soedarto, SH Tembalang, Semarang 1269, Indonesia \\ rahma.restia@gmail.com
}

Received: $18^{\text {th }}$ June 2019/ Revised: 02 ${ }^{\text {nd }}$ July 2019/ Accepted: $12^{\text {th }}$ July 2019

How to Cite: Fatkhiyati, N. R. (2019). Rhetorical strategy and linguistics features in e-petition through Change.org. Lingua Cultura, 13(4), 239-245. https://doi.org/10.21512/lc.v13i4.6104

\begin{abstract}
The research explored what types and how rhetorical strategy correlated with the linguistics features in e-petitions through Change.org entitled "KPK dalam Bahaya". The data were e-petitions collected through Change.org. The analysis was holistically descriptive and included in qualitative research. The approach used critical discourse analysis by Fairclough that was using Fairclough's three-dimensional framework and the strategy of rhetoric by Aristotle. Those theories helped the researcher to find out how the rhetorical strategy and the linguistics features created persuasive meaning. The findings indicate that euphemism, metaphor, connectives, logical connectors, rhetorical questions, and modality support the rhetoric strategy constructing the meaning beyond the words. Through one of the rhetoric strategies, pathos persuades the readers to agree to the argument and sign the e-petitions. Due to the emotional appeals, all of these language instruments help the rhetoric to provoke the readers significantly.
\end{abstract}

Keywords: rhetorical strategy, linguistics feature, e-petition, CDA

\section{INTRODUCTION}

As the internet of things (IoT) has been taken over the world through their apps and their sophisticated objects, one of the technology-based to create life easier is Electronic Petitions (e-petitions). It is divided into two types, formal, which is owned by institutions or government, and the informal one, which is owned by a non-governmental or private organization (Lindner \& Riehm, 2009).

E-petitions contain various information and communication technologies that can be public or private. The e-petitions platform coordinates the signers or users to express their breakthrough about the government or their environment to be changed in a better form (Hagen et al., 2016). If the petitions are shared on the internet, it is public ones, such as Change.org, one of the popular e-petitions platforms in Indonesia. It is easily operated, accessible, and quick to be used by initiators or potential users. It is a new genre of technology-based that has the intention to collect petitions through online platforms and spread actions. The purpose is to create a platform that allows the members of the public to address government decision-makers or other concerns directly with their requests for action. It has a benefit to influence the formulation of policy (Wright, 2015). It is initiated by the initiators, and they are able to collect the petitions easily from a suitable group of people, and the potential signers are free to do actions without big effort. About 21.000 or more campaigns had been successfully attracted the potential signers to help and won the case through the petition in Change.org.

In this research, the issue focuses on the e-petition of "KPK dalam Bahaya" that is initiated by the Indonesia Corruption Watch (ICW). ICW is a non-governmental organization that focuses on anti-corruption awareness since 1970. The goal of ICW is to stop the legalization of RUU KUHP of KPK (Komisi Pemberantasan Korupsi) before August 17, 2018, which in fact, has been started since 2010. ICW needs the people's power to support the cancelation of this legalization due to the threatening of the existence of KPK. The e-petitions are uploaded into Change.org platform to collect supports. In that e-petitions, it consists of a set of verbal language in the form of written text, which uses spoken language form and has a goal to influence people so that they are willing to sign the e-petitions.

Furthermore, throwing back to the fact that the main purpose of the e-petitions is collecting signatures within the petitions, the text should be able to attract the potential signers to support the petition. Due to this goal, this research aims to investigate the linguistics features and the rhetorical pattern using Aristotle's rhetorical strategies as 
the persuasive language in these e-petitions of Change.org entitled "KPK Dalam Bahaya". Both previous researches, which are talking about persuasive language and rhetorical strategies, are focusing on the letter of complaints and political debate. None of them trying to figure out the types of language use in e-petitions in Aristotle's perspective (AlMomani, 2014; Ko, 2015).

However, there is research talking about linguistics features and semantics features in e-petition that is similar to the purpose of this research but has the different object of the research (Hagen et al., 2016). It talks about e-petitions on twitter, while this research needs to discuss more from the perspective of the real e-petitions on the website (Hagen et al., 2016). Moreover, another researcher takes a persuasive study focusing on manipulation in the mode of persuasion by Aristotle (Smithson, 2013). In its finding, the linguistics features take part in the result and give benefits to the research on finding the pattern of the psychopaths. However, the research only uses two of three modes of persuasion; ethos and pathos.

Therefore, based on these gaps, the researcher wants to focus on three modes of persuasion or the rhetorical strategy that correlates with its linguistic feature to build the persuasive effect towards the signers of the e-petition. The aims of this research are; first is to find out types of linguistics features in the rhetoric strategy that construct persuasive language in the e-petitions of Change.org. The second is to understand the pattern of how linguistics features in the rhetoric strategy construct persuasive language in the e-petitions of Change.org. According to these research questions, the significance of this research, theoretically, can broaden the benefit of linguistics features in the rhetorical strategy based on Aristotle's theory and enactive the theory of Aristotle are still compatible. Moreover, the research can be beneficial; practically, if the pattern has been found, it can give benefits to the linguists, writers, journalists, e-petitioners, and parties that want to use the knowledge of rhetorical study and the persuasive language.

\section{METHODS}

The data are collected through e-petitions published in the Change.org platform. The analysis method is holistically descriptive and included in qualitative research. Qualitative research, based on Denzin and Lincoln, is the research method that uses their natural setting, being interpreted, and focusing through particular phenomena in terms of producing meaning (Ospina, 2004). The data are collected through random sampling that the article is chosen randomly from the Change.org platform. The data are analyzed using referential analysis by Sudaryanto (1993) and content analysis by Silverman (2014). The referential analysis is chosen because the data are gathered from words and phrases while the content analysis is chosen because it investigates within the textual context.

The theory used in this research explains about three types of rhetorical strategy based on Aristotle used in the recent e-petitions to be supported entitled "KPK dalam Bahaya" in Change.org. However, this research only puts the limit on the language used in Pathos rhetorical strategy in the e-petitions to be discussed. Aristotle has pointed out that rhetoric is a discipline of the art of using language and has functions to persuade others (Ko, 2015). It also has its own major characteristics, such as perform its style of language to shape or induce attitudes and actions in others and a proper organization of the language to achieve the goal. The goal is around the circumstance or setting. The text producers can use "language, power relations, signs, and logic to selectively alter perspectives, preferences, and attitudes to the audience and the certain issue" (Peng in Ko, 2015). In short, rhetoric is defined as intentionally formed of persuasive communication (Higgins \& Walker, 2012).

According to Aristotle (Ko, 2015; Smithson, 2013), to achieve effective persuasion, there are three essentials elements; they are ethos, pathos, and logos. First, ethos relates to the credibility of the writer or the speaker or the persuader. It is divided into two categories to grab the pattern; intrinsic, and extrinsic that build the trustworthiness of the rhetor. Second, pathos is defined as an emotional appeal. It means that the pattern that is built by it has waking up the emotional side of the reader, the signers, or the persuadee. Last, logos links to the logical side of the argumentation used in the speech or the written text. Logos is also divided into some categories to understand the pattern. There are cause and consequences, analogy, syllogism, definition, testimony and authority, and examples used in supporting a generalization. Through these elements, the arguments open up how the text producers are delivering persuasive communication or the discourse. Therefore, this research will only focus on the pathos elements in e-petitions of Change.org entitled "KPK dalam Bahaya" to examine the rhetorical strategy and the language use.

Moreover, to find out the linguistics features in the e-petitions platform and correlates it with the rhetorical strategy, the researcher uses analysis from Fairclough in the theory of language and power (Fairclough, 2001). Fairclough has divided the analysis into three; description, interpretation, and explanation. The description analysis is needed to find out the linguistics feature such as vocabulary, syntax, grammar, conjunction, and any other linguistics features. Then, it can continue to interpretation and explanation part to discuss how it can relate to the rhetorical strategy and persuasive language.

\section{RESULTS AND DISCUSSIONS}

The data of this research are the e-petitions from Change.org that are initiated by Indonesia Corruption Watch (ICW) organizations to support KPK and to decline the RUU KUHP omitting the right of KPK. The e-petitions are delivered to the members of Change.org through their newsletter and publish it online on the website on June, $4^{\text {th }} 2018$, as the follow-up action of the DPR decisions to accept the RUU on August, $17^{\text {th }} 2018$ to be one of gift in the Independence day of Indonesia.

In the e-petitions, the initiators put the intended meaning beyond the words. Through text analysis that has three stages, the relation between text and context can be found, there are descriptions, interpretations, and explanations (Fairclough, 2001). In the description stages, there are three sets to do text analysis in terms of vocabulary, grammar, and textual related to its experiential, relational, and expressive values.

As it has been explained in the previous parts of this research, Aristotle has three rhetoric strategies starting from ethos, pathos, and logos. Ethos deals with ethical appeals that build credibility and trustworthiness from the writer to convince the reader. Pathos deals with emotional appeals that feeling affect-judgment and judgment-affect 
way of thinking. It provokes the readers of e-petitions to be enthusiastic to support the petitions. Logos deals with rational appeals that pointing out facts, data, and reasons (Aristotle, 2007).

Moreover, within the mode of persuasion in the rhetorical strategy, there lies textual analysis (Smithson, 2013). In textual analysis, the linguistics features are discussed clearly. These features are discussed in the level of vocabulary, syntax or grammar, and rhetorical devices. The interpretation in textual analysis functions to describe what it is about, how it is constructed, and what is it for in the text. The text is a sampling of reality. Even though it is far from reality, the sampling can open the perspectives widely. In this phase, within the experiential value, the vocabulary leads the words revealing the meaning beyond the text. The initiators use some linguistics features to point the issue out.

The trustworthiness of the e-petition is regarded with ethos. It helps the rhetor to convince the readers or the signers through extrinsic and intrinsic factors of ethos. Extrinsic factors cover 'the character, the expertise, the education, and the experience of the rhetor' (Aristotle, 2007), while the intrinsic factors refer to how the writer writes or speaks through the rhetorics.

Indonesian Corruption Watch (ICW) is a NonGovernmental Organization (NGO) that focuses on anticorruption awareness. This kind of NGO has existed since 1970 (Permata, 2017). ICW has started to focus on the Revision of UU KPK since the issue had been begun in 2010. Then it continued to 2015 and finally declined in 2018 with support from the e-petition of Change.org. ICW helps the public to get justice through doing advocacy. ICW has many experiences in doing this kind of activity. In 2018, before the revision of UU KPK finally stopped, ICW has gathered the e-petitions result and send it immediately to the legislative or DPR. The e-petitions show the public protests throughout Indonesia represented by ICW. Furthermore, the discussion in the regular meeting of DPR discussing the revision of UU KPK has been declined. Therefore, the extrinsic of ethos rhetoric factor is well-considered in the requirements to be a trustworthy rethor.

ICW works based on data and research. Moreover, ICW also builds a relationship and doing lobbying with the government. Not only lobbying, ICW does more on framing and labelling and cooperate with media to create a supportive condition to achieve the goal of advocacy. All of those activities are the effort of ICW to compile supports from every single area. In doing a public mobilization, ICW uses the Change.org e-petition for persuading society through rhetoric.

Beside extrinsic and intrinsic factors, ethos also correlates with the persuader branding of personality towards the persuadee. The persuader needs to connect with his or her persuadee to persuader the image or character that he or she builds in terms of receiving supports (Smithson, 2013). The theory of ethos can be linked to textual function from Halliday, especially in the theory of interpersonal function as the definition of the listener and speaker's relationship. The realization of the textual function is focusing on the interpersonal system that can be analyzed through the linguistics techniques, such as lexical choice and repetition, modality, and question/rhetorical question (Smithson, 2013).

The examples of lexical choice can be seen in this example (1):
(1) Komisi Pemberantasan Korupsi (KPK) dalam bahaya.

(2) Di mana letak bahayanya?

(3) Presiden Joko Widodo dan Ketua DPR serta Ketua Umum dari Partai Politik di DPR untuk segera menyelamatkan KPK dari bahaya dengan segera menarik seluruh aturan atau delik korupsi dalam $R$ KUHP.

The lexical choice appears in Change.org's article; there is also lexical repetition within. In the example (1) lines 1, 2, 3, all of the examples repeat the lexicon 'bahaya' (danger). The persuader or the writer focuses on the necessary point of the article that "KPK is in danger" because of the RUU KPK. The persuader needs to build the impression that there is something wrong with the RUU $\mathrm{KPK}$, and it leads to the ending of KPK soon if the RUU KPK is legalized. The lexical choice of the writer reflects the representation of the personality of him or herself (Smithson, 2013). Moreover, the repetition of the lexical item cements the idea or the image of the failed project of RUU KPK towards KPK that sooner or later, it can stop the productivity of KPK.

The writers choose the word 'bahaya' (danger) to point out that this issue is significant and urgent. The writer wants to make the readers feel for KPK. Through this emotional manipulation, the text producer collects the supports from the members of Change.org. In the transitivity process, 'bahaya' (danger) includes in the mental process as attributive. The mental process is a process of sensing. It is divided into three; a process of perception, affection, and cognition. In this rhetorical strategy, a sensing process is implied in the form of caution words 'bahaya' (danger). The rhetorical strategy used by the writer considers these aspects of the mental process. The writer considers the perception area about the topics. It shows that the issue is genuinely urgent.

In the e-petitions, sometimes the writer exploits questions to construct the text so it can feel more personal. In line 2 example (1), the question engages the reader deeper through the rhetorical question. It is shown off in the text aiming to get something in return indirectly, such as an elicit answer. The rhetorical question has an apparent answer for both sides, addressee, or the addresser (Špago, 2017). By using questions, the writer has a plan to create a closer relationship between the writer and the readers that shows the informality between them. It shortens the distance through language devices. Such in Špago (2017), a question is identified as a rhetorical form. It relates to the finding here is the rhetorical form sets the goal to persuade the readers indirectly.

The example (2) shows the modality:

(1) Kondisi ini terjadi karena DPR dan Pemerintah akan segera mengesahkan Rancangan Kitab Undang-Undang Hukum Pidana (RKUHP) pada 17 Agustus 2018 mendatang dan terdapat subtansi di dalamnya yang dapat mengancam eksistensi KPK maupun upaya pemberantasan korupsi di Indonesia.

(2) Pada akhirnya KPK hanya akan menjadi Komisi Pencegahan Korupsi.

(3) Mengakomodir delik korupsi masuk ke dalam RKUHP hanya akan menimbulkan citra buruk bagi rezim pemerintah dan parlemen saat ini. 
(4) Presiden juga dinilai ingkar janji dengan poin ke-4 "NAWACITA" yang menyatakan akan memperkuat penegakan hukum dan pemberantasan korupsi.

(5) Presiden Joko Widodo dan Ketua DPR serta Ketua Umum dari Partai Politik di DPR untuk segera menyelamatkan KPK dari bahaya dengan segera menarik seluruh aturan atau delik korupsi dalam RKUHP.

(6) Pemerintah dan DPR agar lebih memprioritaskan pada pembahasan regulasi atau Rancangan Undang-Undang yang mendukung upaya pemberantasan korupsi seperti Revisi UU Tipikor, RUU Pembatasan Transaksi Tunai dan RUU Perampasan Aset Hasil Kejahatan.

Modal verbs in English or modal verbs are used to show probability, intention, or obligation (Smithson, 2013). In this e-petition, the function of 'will' in the present tense is beneficially to communicate the probability of the event if the R-KUHP is legalized. Most of the probability argues about the setbacks if the government agree to legalize RKUHP as it can be seen in the example (2) line 1 to 4. By using the setback's argument, the persuader wants to attract the signers to see the negative sides of the RKUHP for KPK itself. Then, the writer wants to persuade them to be one of the signers that help KPK away from the setbacks. In line 1, the modal verb 'will' is followed by the lexicon 'threaten' (mengancam). It means that the writer expresses the next negative events will threaten the KPK's existence if the signers do not help ICW to cancel RKUHP. In line 2, the writer predicts the ending of future events if RKUHP is accepted by using modal verb 'will'. In line 3, the bad image of the legalization of RKUHP will take down the good reputation of the government. Last, in line 4, it has similarity to the line 3 that the image of the government will be broken.

Moreover, the modality of 'akan' or 'will' shows relational or expressive value in the sentence. It depends on the purpose of the modality. Because the modality has to do with the writer or the text producer, the purpose is significant to find out. By using 'will', the sentence is oriented in persuading the readers or members of Change. org to sign the petition and support the text producer to decline the RKUHP. Therefore, the meaning beyond the words, there is helped by the modality to show the expressive value or as if it is a representation of reality called it as 'the evaluation of truth' (Fairclough, 2001). It comes from the data, and the argument ends the opinion based on the writer or text producer's perspective. It relates to Fairclough's arguments that said: "It is precisely implicit authority claims and implicit power relations of the sort illustrated here that make relational modality a matter of ideological interest" (Fairclough, 2001). The power of the writer within the words manipulates the readers to agree with the argument expressively and emotionally. It is one of the phatos characteristics.

In line 5, the writer uses modality again in terms of suggestion. The writer uses 'segera' that means 'ought' or 'must' in English. This modality illustrates the language use here performing the writer as if he/she has more authority than the President of Republik Indonesia and DPR. It manipulates the readers to support the writer's suggestion because the members think that the action is the right thing to do. In line 6, the word 'agar' or 'should' as modality used by the writer points out the obligation of the government is to prioritize and support the concern of the corruption. The writer needs to manipulate the readers understanding that outside the obligation is not that significant and urgent to prioritize. The emotional appeals are the writer concern to get the readers attention.

Phatos leads the rhetoric to 'a pathetic appeal' (William, 2019). It affects the emotional part and selfinterest of the readers or signers to be more convincing on the speech or writing. In this e-petitions article, ICW tries to make the signers being aware and anger. The useful method that the persuader uses in the e-petition is a metaphor. Metaphor affects the emotion of the signers through 'linguistics emotivity' (Smithson, 2013). Example (3) of metaphors can be seen here:

(1) Kondisi ini terjadi karena DPR dan Pemerintah akan segera mengesahkan Rancangan Kitab UndangUndang Hukum Pidana (RKUHP) pada 17 Agustus 2018 mendatang dan terdapat subtansi di dalamnya yang dapat mengancam eksistensi KPK maupun upaya pemberantasan korupsi di Indonesia.

(2) Triliunan uang Negara berhasil diselamatkan; puluhan koruptor telah dijaring dalam Operasi Tangkap Tangan.

Line 1 example (3) shows that the word 'mengancam' on of metaphors is used by the writer to show the urgency of declining revision of UU KPK because it can threaten the impact of KPK in opposing corruption in Indonesia. The writer used the word 'mengancam' as if RKUHP is animate. Metaphors are, in example (3), to show the words coming to life. It reflects the reality so that the writer can point out that this issue is very dangerous for the rest of the corruption cases out there if the RKUHP is going to be legalized soon. This metaphor is representing an aspect of experience and stereotypically associated with the meaning beyond the words. At the beginning of the paragraph, this word is written by the writer to bold that this is a serious problem. Society should concern about this issue and pay attention to the cause after the RKUHP being signed soon. By pointing this out, the writer expects to get more support on this e-petition. The metaphor is constructed to be a dominant interest in the e-petitions. The after-effect of the metaphors is needed to support the e-petitions.

There is a difference in the language used in mentioned the text. The writer uses overwording and metaphor to describe 'money' as if it is valuable to be saved or 'diselamatkan' rather than 'diamankan' or being kept. While for defining corruptor, the writer chooses to use 'dijaring' or 'being caught' as if the corruptor is the fishes that have no value in life rather than using 'ditangkap' or being arrested. The language choice to define one object to another object has meaning beyond the words. The writer needs to explain that KPK saves a life by saving money and jailing corruptors.

The euphemisms are combined with the metaphors to show how the word 'diselamatkan' or 'to be saved' is mentioned. The writer seems like having the purpose of softening the urgency of the money. By keeping the money saved, the actor in the article is a hero afterward. Therefore, the money should be in the first place compared to the corruptor that has no value.

Logos defines the 'logical appeal' (William, 2019). The persuader ought to build trustworthiness through the logical appeal of the writing content. It is needed to make the signers believe the claim and proof reasonably. These 
argumentations have different forms, natural, and artificial proof. The natural forms are based on the given data, such as testimony, document, and others (Aristotle, 2007). While artificial proof is based on the created data and its combination, such as the example for supporting data, hints, etc. Moreover, the category of the argumentation of logos is divided into several parts; cause and consequences, analogy, testimony and authority, definition, syllogism, and support a generalization with example.

Example (4) is the example of cause and consequences in writing e-petitions:

(1) Pertama, jika RKUHP disahkan maka KPK tidak lagi memiliki kewenangan dalam melakukan penyelidikan, penyidikan dan penuntutan.

(2) Mengakomodir delik korupsi masuk ke dalam RKUHP hanya akan menimbulkan citra buruk bagi rezim pemerintah dan parlemen saat ini.

(3) Jika delik korupsi dimasukkan dalam KUHP, maka hanya Kejaksaan dan Kepolisian yang dapat menangani kasus korupsi.

Cause and consequences are defined by the claim about a thing that causing or being caused by other things. In this e-petition, the logic refers to the logical connectors used by the writer are shown in the example (4) in line 1 and 3. Most of the logical connectors are used in this e-petition is a conditional connector. It shows two ideas being connected into one sentence. It leads to a particular condition about what condition will happen if that condition is met. These connectors try to predict or to create possibilities by showing off several ideas and persuading the signers. These ideas support the argument and persuade the signers to also agree to the arguments even though the ideas connected by the conditional connectors can be not-qualified enough.

In these sentences, the writer uses a coordinating conjunction or connectives. It establishes the relationship between one clause to another clause. Both clauses are dependent on each other for their meaning. The connectives help the writer to construct the intended meaning to this sentence. The coherence of the sentence depends on the assumption of the intended meaning built by the connectives. The writer exploits this assumption to bring the emotional up, and the readers want to sign the e-petitions or to click further information in it.

The connective used by the writer is coordinating connectives or conjunction. While it connects two clauses or two ideas, it also suggests a contrast that is unexpected in the first clause. The implied meaning usually relies on the second part of the sentences or the negative part. The connectives of the sentence help the writer to construct the presupposition of the reader. It happens because one of the clauses is more prominent than the others. So the meaning is automatically presupposed. By presupposing the meaning, the emotional part of the people or society will lead in front of the other, and the writer can easily persuade the readers through this strategy.

Example (5) shows the example of analogy in writing e-petitions.

(1) Pemerintahan Jokowi dan Partai Politik yang ada di DPR nantinya akan tercatat sebagai lembaga yang melemahkan KPK dan upaya pemberantasan korupsi.
The analogy shows the comparison between one claim to another to build the trustworthiness of the issue. In the e-petition, to cement one another ideas, the writer use conjunction 'as' or 'like'. The persuader needs to make sure the signers know both ideas that support the e-petition so that they, the signers, can make a decision whether they sign the e-petition or not. Mostly, in this e-petition, the analogy used in the petition is negative. The negative analogy brings out the anger side of the signers or the emotional one. Therefore, it is a good thing for the persuader to bring out the negative ideas out.

Example (6) shows the testimony and authority in writing e-petitions.

(1) Kewenangan KPK tercantum dalam UU KPK yang secara spesifik menyebutkan bahwa KPK berwenang menindak tindak pidana korupsi yang diatur dalam UU Tipikor (dan bukan dalam KUHP).

(2) Sudah menjadi rahasia umum bahwa pada masa lalu Pengadilan Negeri kerap memberikan vonis ringan bahkan tidak jarang membebaskan pelaku korupsi.

Most of the arguments in this e-petition provide opinions from other sources besides the rhetor or the writer. In line 1, the writer has cited the power of KPK based on UU KPK. Then, the writer has also cited past events on the e-petition to provoke the signers to support the e-petition. The sentence, "Sudah menjadi rahasia umum," in example (6) in line 2, means that "people already know" that in the past years, the district court gives a light sentenced to the corruptor. Therefore, the district court is far from trusted.

Example (7) shows the definition in e-petitions.

(1) Kondisi ini terjadi karena DPR dan Pemerintah akan segera mengesahkan Rancangan Kitab Undang-Undang Hukum Pidana (RKUHP) pada 17 Agustus 2018 mendatang dan terdapat subtansi di dalamnya yang dapat mengancam eksistensi KPK maupun upaya pemberantasan korupsi di Indonesia.

(2) Ancaman pidana penjara dan denda bagi koruptor dalam RKUHP lebih rendah dari ketentuan yang diatur dalam UU Tipikor.

(3) Lebih ironis adalah koruptor yang diproses secara hukum dan dihukum bersalah tidak diwajibkan mengembalikan hasil korupsinya kepada negara karena RKUHP tidak mengatur hal ini.

(4) Selain itu pelaku korupsi cukup mengembalikan kerugian keuangan negara agar tidak diproses oleh penegak hukum.

In the definition, it describes the issue or the nature of the problem. In the example (7) in line 1, the definition of RKUHP is later going to be a setback discussed further. So, the readers of the signers can understand deeply about it. Through the understanding, the signers can make a decision to sign the e-petition. In line 2 and 3, the definition involves a comparison between the ideas using comparative verb 'lebih' or 'more'. While in line 4, the definition gives more reasons after the comparison. These shreds of evidence, hopefully, can attract the signers to think clearly and support the e-petition to cancel the RKUHP.

The example of syllogism in e-petitions can be seen in example (8). 
(1) Tidak hanya KPK, akan tetapi Pengadilan Tipikor pun terancam keberadaannya.

(2) Selama ini Pengadilan Tipikor hanya memeriksa dan mengadili kejahatan yang diatur dalam UU Tipikor 11. Maka jika RKUHP ini disahkan kejahatan korupsi akan kembali diperiksa dan diadili Pengadilan Negeri. Pada akhirnya KPK hanya akan menjadi Komisi Pencegahan Korupsi.

Syllogism involves deductive logic using major, minor premise, and conclusion. The move from general to particularly specific creates syllogism in the text (William, 2019). The writer puts the reason before the conclusion to persuade the readers so they can sign the e-petition. The premise offers a logical perspective on the e-petition that can persuade the readers or the signers. The conclusion is ended with "pada akhirnya" in the example (8) in line 2. While in line 1 , the writer focuses on the ending while in the previous sentences places the reasons.

Example of the support a generalization with example can be seen in example (9).

(1) Aturan ini sekaligus menjadi kontra produktif dengan kinerja KPK yang telah teruji selama ini. Delapan triliunan uang negara berhasil diselematkan; puluhan koruptor telah dijaring dalam Operasi Tangkap Tangan; seluruh terdakwa korupsi yang dijerat dan dibawa ke persidangan selalu dinyatakan terbukti bersalah oleh hakim (100 percent conviction rate). Pelaku korupsi yang ditangkap adalah koruptor kelas kakap mulai dari Ketua DPR, Ketua DPD, sampai Ketua Mahkamah Konstitusi.

(2) Presiden juga dinilai ingkar janji dengan poin ke-4 "NAWACITA" yang menyatakan akan memperkuat penegakan hukum dan pemberantasan korupsi.

In this category, the involvement of the example makes the ideas stronger. The example can be the proof or evidence of the statement of the issue. The writer has an intention behind the example to build trustworthiness through logos. Therefore, it seems logical and trusted to be followed or signed. In line 1, the writer tries to show that the RKUHP has an issue with the existence of KPK. For line 2, the writer puts an example regarding the public opinions about the president if the president agrees to sign the RKUHP. These examples help the writer to achieve the supports that are needed.

According to these discussions, the mode of persuasion or the rhetorical strategy based on Aristotle (2007) is constructed through three modes, ethos, pathos, and logos. Then, each of them is built by the linguistics features that help the writer persuades the potential signers (Smithson, 2013). According to Smithson (2013), in her research about the manipulative purpose that correlates with the rhetorical strategy of Aristotle, the finding has stated that the speaker mostly avoids negative emotion that has different results with the e-petition in Change.org. In the e-petition, most of the ideas show the negative issue to attract and persuade the signers. Even though the result is different, the category used by the writer or persuader is similar, from ethos to logos, from cause and consequences to example to support a generalization.

\section{CONCLUSIONS}

In the e-petition, the purpose of a text is to persuade the members of Change.org to support a particular campaign. Based on the result, the rhetor uses the rhetorical strategy of Aristotle to persuade the signers in some ways through ethos, pathos, and logos. In ethos, besides the writer uses extrinsic and intrinsic factors, some linguistics features affect how the writer brand his/her images by using lexical choice, modality, and rhetorical question. In the lexical choices happens the repetition of lexical choice: 'bahaya' or 'in danger'. The rhetor wants to make this focus necessary and important so that the signers will pay attention more to the issue and sign the e-petition. In modality, most of the modal verb used by the rhetor is 'will' or the modal verb of probability. The rhetor has the goal to build the branding of the good image towards ICW and KPK while it is different in the opposite way, like DPR, government, and RKUHP.

Then, the rhetorical question is also used in the e-petition to emphasize the issue that is still running at that time easily. In pathos, metaphors help the rhetor to achieve the goal. In other ways, metaphors that are combined with euphemism works well. While in the previous research, the content is showed off positively to make people believe, in this area, the content is more negative. In logos, conjunction, connectives, and comparative sentence are spread in the categories. These support the writer to provoke the signers in the matter of the logical appeal.

Practically, the practitioners in writing, journalist, and linguist can find out the pattern to build a new persuasive article to achieve a similar goal. Theoretically, it broadens the knowledge about persuasive language on e-petitions. In future research, other researchers can make a further finding in the specific areas of Aristotle's mode of persuasion within different areas.

\section{REFERENCES}

Al-Momani, K. R. (2014). Strategies of persuasion in letters of complaint in academic context: The case of Jordanian University students' complaints. Discourse Studies, 16(6), 705-728. https://doi. org/10.1177/1461445614546257.

Aristotle. (2007). On rhetoric: A theory of Civic discourse (Second edition). Oxford: Oxford University Press.

Fairclough, N. (2001). Language and power ( $2^{\text {nd }}$ edition). Abingdon: Routledge.

Hagen, L., Harrison, T. M., Uzuner, Ö., May, W., Fake, T., \& Katragadda, S. (2016). E-petition popularity: Do linguistic and semantic factors matter? Government Information Quarterly, 33(4), 783-795. https://doi. org/10.1016/j.giq.2016.07.006.

Higgins, C., \& Walker, R. (2012). Ethos, logos, pathos: Strategies of persuasion in social/environmental reports. Accounting Forum, 36(3), 194-208. https:// doi.org/10.1016/j.accfor.2012.02.003.

Ko, H. (2015). Political persuasion: Adopting Aristotelian rhetoric in public policy debate strategies. International Journal of Humanities and Social Science, 5(10), 114-123. 
Lindner, R., \& Riehm, U. (2009). Electronic petitions and institutional modernization: International parliamentary e-petition systems in comparative perspective. JeDEM - EJournal of EDemocracy and Open Government, 1(1), 1-11. https://doi. org/10.29379/jedem.v1i1.3.

Ospina, S. (2004). Encyclopedia of leadership. London: Sage Publication.

Permata, A. G. (2017). Peran Indonesia Corruption Watch (ICW) dalam melakukan advokasi untuk mencegah revisi Undang-undang nomor 30 tahun 2002 tentang komisi pemberantasan tindak pidanakorupsi tahun 2010 dan 2015. Unpublished Thesis. Depok: Universitas Indonesia.

Silverman, D. (2014). Interpreting qualitative data: Methods for analyzing talk, text, and interaction. London: SAGE Publication. https://doi.org/10.1016/ B978-0-12-012755-9.50004-8.
Smithson, R. (2013). Rhetoric and psychopathy : Linguistic manipulation and deceit in the final interview of Ted Bundy. Diffusion: The UCLan Journal of Undergraduate Research, 6(2), 1-13.

Špago, D. (2017). Rhetorical questions or rhetorical uses of questions? ExELL, 4(2), 102-115. https://doi. org/10.1515/exell-2017-0009.

Sudaryanto. (1993). Metode dan aneka teknik analisis bahasa: Pengantar penelitian wahana kebudayaan secara linguistis. Yogyakarta: Duta Wacana University Press.

William, G. H. (2019). Ethos-pathos-logos: The 3 rhetorical appeals. Retrieved from http://georgehwilliams. pbworks.com/w/page/14266873/Ethos-PathosLogos-The-3-Rhetorical-Appeals.

Wright, S. (2015). E-petitions: The handbook of digital politics. USA: Edward ELgar. 